\title{
THE INFLUENCE OF A GREEN IMAGE AND CUSTOMER SATISFACTION TOWARDS CUSTOMER LOYALTY IN THE HOTEL INDUSTRY
}

\author{
Yusnita, $\mathrm{Y}^{1}$, Yahaya Ibrahim ${ }^{2}$ and Zainudin Awang ${ }^{3}$ \\ 1,2 Faculty of Applied Social Sciences, Universiti Sultan Zainal Abidin, \\ ${ }^{3}$ UniSZA International Centre, Universiti Sultan Zainal Abidin, Malaysia
}

\begin{abstract}
Tourism is currently one of the largest sectors in the world and has contributed to world economic growth. Malaysia, in recent times, has become one of the most visited countries in Southeast Asia. An increase of tourist arrivals (from both domestic and international visitors) has caused an increase in the number of accommodation that is available each year, and places the hotel industry as one of the most popular segments in the tourism industry. Since environmental awareness has been increasing across the world, a green image is seen to be an important aspect to be explored in the hotel industry in current times. Thus, the aim of this study is to examine the influence of a green image towards customer satisfaction and customer loyalty among a hotel's guests in the Malaysian hotel industry.
\end{abstract}

Keywords: Green Image, Customer Satisfaction, Customer Loyalty, Hotel Industry, Malaysia

\section{INTRODUCTION}

Malaysia is one of the most popular tourist destinations in Asia. According to UNWTO (2014), international tourist arrivals to Asia and the Pacific increased by 6 percent to 248 million visitors in 2013 over the previous year. From this number, the Asia-Pacific region showed the highest increase of 6\% compared to Europe and Africa that showed increases of $5 \%$. As expected, Southeast Asia was fastest growing destination in the region and in the world for two consecutive years (2012 and 2013). Through this increment, this sector has the potential for infrastructure development and in providing sufficient employment opportunities to residents (UNWTO, 2014). However, since tourism involves the interaction between humans and the environment, the increase of tourist arrivals and tourism activities is seen to give an impact on the environment (Siti Nabiha et al., 2011).

According to the Central Intelligence Agency (CIA) (2015) and Zam Zuriyati et al. (2014), environmental issues has plagued Malaysia for some time, which include water pollution, air pollution, waste disposal, climate change, global warming, deforestation and haze. According to Siti Nabiha et al. (2015), Malaysia still lack of tourism strategy in place at the national level; however, there are a few plans and policies that are relevant to a few national development plans namely the Five-Year Malaysia Plan, the National Tourism Policy and the National Ecotourism Plan. The $10^{\text {th }}$ Malaysia Plan concentrated on the steps to solve global warming, environmental conservation and sustainability, while the $11^{\text {th }}$ Malaysia Plan (20162020) will emphasise on proposing policies and regulations, human capital development and green technology investments. This plan will also enhance the country's economy through the cooperation from all agencies including the government as well as private and non-profit organizations. In this $11^{\text {th }}$ Malaysia Plan, four focus areas were given priority, such as strengthening the resilience to climate change and natural disasters, enabling the environment for green development, adopting the

Corresponding Author: yusnitayusof@ unisza.edu.my 
concept of sustainable consumption and production and conservation of natural resources for present and future generations (Economic Planning Unit, 2015).

According to Lita et al. (2014), attention to the environmental issues and business practices is more popular in developed countries compared to developing countries, particularly in the aspect of community awareness and government policies and regulation. This statement supported the research by Kang et al. (2012), which found that the world's leading hotels have taken their own initiative to invest in environmentally friendly practices a few years ago. Furthermore, according to Abdul Samad et al. (2008), hotels in Malaysia are more focused on facilities and services rather than environmental policies and practices. Based on previous research, a number of hotel management teams were hesitant to take the initiative in carrying out green practices in their hotel because they are not certain whether these provide value or not to the customers (Nor Azila and Kumar, 2014) and are uncertain of the need of becoming green (Smith and Perks, 2010).

Recently, research about image has become the focus among researchers as well as the management of organizations because it involves employee or customer behavior in making decisions (Han, Hsu
\& Lee, 2009). However, until 2010, there has been no research focused on a green hotel's image from the perspective of hotel guests (Lee et al., 2010). Research by Bell (2008) indicates that there is also limited research linking green practices and hotel image in the hospitality sector.

Since the hotel industry makes a huge impact on the environment from the construction and daily operations which can bring about effects of climate change, it seems that this industry is an important one to be explored. Green hotels, also called ecofriendly hotels, ecologically friendly hotels or environmentally friendly hotels, are institutions that eagerly follow water and energy saving practices, solid waste reduction, and cost saving to help in protecting our earth (GHA, 2013). According to ASEAN (2013), a green hotel is an environmentally friendly hotel that practices energy conservation. This concept of hotel development is one of the initiatives made to protect and conserve the environment. From all the registered hotels with the Ministry of Tourism and Culture up until November 2014, only 10 of 1935 hotels were awarded as green hotels in Malaysia by ASEAN and this is illustrated in Figure 1.4. This number indicates there are still very few hotels that recognize the importance of utilizing green practices in their hotel and the need for green hotels is constantly increasing.

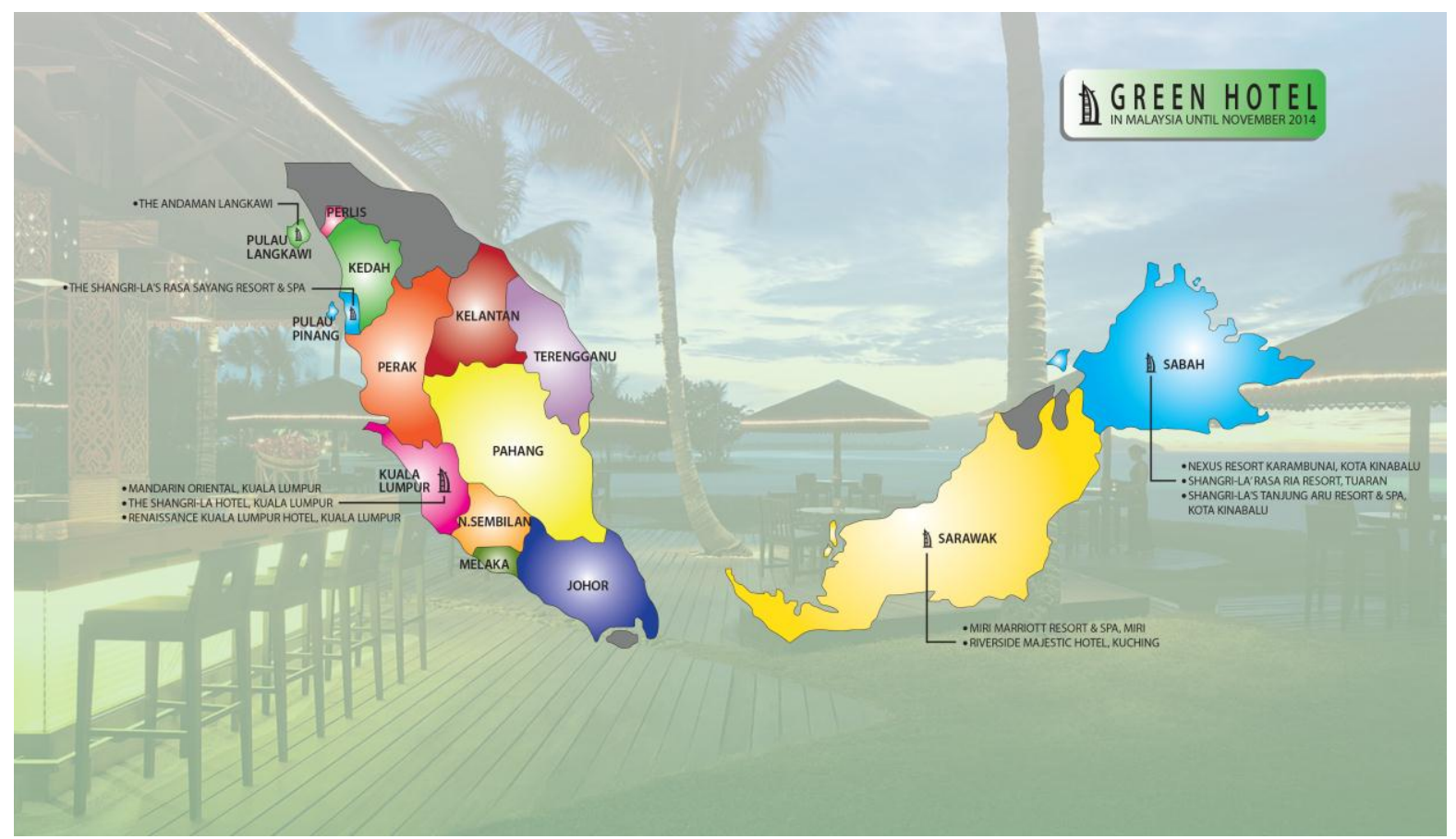




\section{LITERATURE REVIEW}

According to Lee et al. (2014), various definitions of brand image began over the last six decades through specific terminology. Initially, the concept of brand image was associated with the cognitive and effective perspective, then in the 1980 s, the concepts of image related to the symbolic meaning of products. Beginning in the 1990s, service image was considered part of the brand image concept. However, the product image concept is now described as a separate term from brand image. The image concept of a firm has attracted increasing attention from both academia and industry, because it is believed to play an important role in customer's decision-making process (Han et al., 2009) and behavior (Kotler \& Gertner, 2002). Furthermore, image of the company plays a vital role in distinguishing it from another company (Jeong \& Jang, 2010). According to Han et al. (2009), overall image refers to hotel customers' overall perception towards green hotel, formed by information and knowledge about green hotels and its attributes. Image gives an impact to the customer behavior in buying or consuming good and services (Kadampully \& Suhartanto, 2003). Image also creates a first impression for the customer, thus an attractive image can create good word of mouth from previous customers and can attract new customers (Khan, 2013). Thus, a green image refers to the perception of the guest towards the green characteristics provided in the hotel. Since this research covers non-green hotels, a green hotel image is the perception of the guest towards the green attributes provided in the hotel as a whole. Echtner and Ritchie (1991) classified image into two dimensions, namely holistic and attributes. Holistic refers to the picturing of the phenomena as a whole in the individual's mind, while attributes refer to the facilities and physical environment that influence the phenomena. Thus, the attributes in this research focus on the perception of the customer towards physical facilities, interior design, price, the quality of the products provided and staff performance, while holistic is the perception of the customer towards a hotel's atmosphere, reputation, external appearance and hotel layout as suggested by Kandampully \& Suhartanto (2000).

Customer satisfaction has been a popular topic in academic research, especially in marketing research since the initial study done by Cardozo (1965) on customer effort, expectations and satisfaction. Customer satisfaction is an essential factor to provide revenues and profits and one of the critical components of the hotel industry's position of value to a guest (Maghzi, Abbaspour, Eskandarian, and Abdul Hamid, 2011). To ensure customer satisfaction is achieved, it is important to recognize and anticipate customer needs (Dominici and Guzzo, 2010). This statement is agreed by Ranjbarian et al. (2011) who states that customer satisfaction is related to the needs and expectations of the customers towards several factors, such as previous personal experience, well known products or what the company has promised and the price of the goods or service. Customers are satisfied if they have positive feelings that result from having received beyond what was expected, including the purchase decision and the needs associated with the purchase (Armstrong \& Kotler, 1996; Wiele, Boselie \& Hesselink, 2002; Akbar \& Parvez, 2009). Customers will respond positively if the products and services meet or exceed their requirements. However, if their needs are not met, they will respond differently.

Since the cost of attracting new customers is higher than the cost of retaining the existing ones, in order to be successful managers must concentrate on retaining existing customers by implementing effective policies for customer satisfaction and loyalty (Dominici and Guzzo, 2010). Customer loyalty refers to the strength of the relationship between an individual's attitude towards product, brand, service, store or vendor and repeat patronage. According to Oliver (1999), customer loyalty consists of both attitudinal and behavioral commitment to the relationship, such as being price insensitive, giving positive word of mouth and repeat patronage. Attitudinal loyalty is closely related to the power of psychology and attitudes towards products or services offered at the green hotels. Customers who have high attitudinal loyalty will endure and resist attempts in contrary directions. It is likely to influence behavior among customers. According to Allen and Wilburn (2002), loyalty has two constructs namely affective loyalty and cognitive loyalty. Affective loyalty is based on emotions and interactions between people, while cognitive loyalty involves perception towards what is being offered such as price, accessibility and punctuality. Most hotels are now faced with the challenge of meeting and further exceeding these customer expectations to ensure repeat patronage, which is the bedrock of any business (Caruana, Money \& Berthon, 2000). Although several factors have been reported as relevant for gaining customer loyalty, nonetheless, 
customer satisfaction is highly recognized for its fundamental role (Jamal \& Naser, 2002). According to Nurul Syaqirah and Putra Faizurrahman (2014), the success of the tourism industry, especially in the hotel sector, depends on the customer satisfaction. Moreover, an emotional link to customer loyalty is one of the key strengths of any green product (Hartmann \& Ibanez, 2006). According to Nurul Syaqirah and Putra Faizurrahman (2014), one of the factors that influence customer satisfaction and customer loyalty in the hotel industry is the perception towards physical aspects and tangible dimension, or more commonly known as image. An article reviewed by Cohen, Prayat and Moital (2014) on Customer Behavior literature published in three major tourism journal namely Annals of Tourism Research, Tourism Management and Journal of Travel Research from 2000 to 2012 reveals that from 519 articles, 117 article research on satisfaction, trust and loyalty. It is shows that, this kind of concepts is the leading compared to others. This means concept of satisfaction and loyalty is the most important conceptual dimensions of tourism customer behavior research.

Green hotels refer to properties that have programs or activities conducted by the management that are environmentally friendly, can save energy and water and can improve waste management (GHA, 2013; Alexander, 2002). According to Alexander (2002), by the efficient use of water, energy and materials, the green hotel can reduce cost and liabilities, receive higher returns with low-risk investments and expand profits. By relating with socio-economy elements, Kasim (2004) explains the operation of a green hotel should be in an accountable approach towards employees, society, local culture and environment, while from a business view, it is related to decisionmaking and green thinking. Wolff (2008) and Heisterkamp (2009) agree that consumers expect more by green hotels need to be more socially and environmentally responsible. According to Han, Hsu and Sheu (2010), eco-purchasing and recycling are also activities that can reduce negative impacts on the environment. This paper looks at the perceptions of the customer towards a non-green hotel; a non-green hotel refers to the hotel that has been registered with the Ministry of Tourism and Culture, Malaysia, but has not been awarded as a green hotel by the ASEAN Tourism National Organization. However, this type of hotel has the probability of adopting a green image in their hotel even though not it has not been awarded as a green hotel. Thus, this paper is to answer the two objectives as follows.

\section{OBJECTIVES}

1. To examine the level of green image in the hotel industry in Malaysian non-green hotels

2. To examine the influence of green image towards customer satisfaction and customer loyalty among a hotel's guests in the Malaysian non-green hotel industry

\section{METHOD}

\section{Participants}

Since this study involved hotel customers and the number of study population cannot be determined, the researcher used sample frame design as suggested by Burns and Bush (2014) named Confidence Interval Method. The sampling frame for this study was created based on the valuable questionnaires with the population (N) size of 932 .

The calculated sample (n) size is between 96 and 384 . However, as an additon to obtain an adequate and appropriate number of samples, the researcher also used the sampling size formula by Krejcie and Morgan (1970). By using this formula, the final number of respondents that are usable for analysis is 265 respondents.

\section{Measures}

This study involves three sections of questionnaire. For green image, the questions were adapted and modified from Kandampully \& Suhartanto (2000). After having conducted the Exploratory Factor Analysis, the final number of items for this construct was 9 items. For the customer satisfaction construct, there were 14 items developed. The items were adapted from the questions that were modified by Skogland and Siguaw (2004).

While for the customer loyalty questions, this research referred to the questionnaire that was modified by Al-Rousan, M. Ramzi and Badaruddin (2010) and Skogland and Siguaw (2004) to ensure that the questionnaire is compatible with these studies, and consists of 8 questions. 
All responses for all constructs were recorded on a 10-point Numerical Scale with $1=$ "strongly disagree" and $10=$ "strongly agree". There are several reason why this research used a larger scale the 10-point scale, which include to have more variance to determine the variable, to give a higher level of accuracy of measurement, to minimize the leniency problem, central tendency and the "halo effect" associated with the scales and also because it is suitable for advanced statistical analysis technique (Hill, Roche and Allen, 2007; Coelho \& Esteves, 2007; Wittink and Bayer, 1994; Walker, 1994).

\section{RESULTS}

Based on demographic analysis, among the respondents were $44.9 \%$ male (119 respondents) and $55.1 \%$ female (146 respondents). The majority of respondents were teenagers, where $49.1 \% \quad(130$ respondents) were between 21 to 30 years oo age, followed by $24.5 \%$ (60 respondents) who were between 31 to 40 years old, $13.6 \%$ (36 respondents) who were between 41 to 50 years of age, $9.8 \%$ (26 respondents) who were below 20 years of age, and the remaining $3 \%$ ( 8 respondents) who were aged between 51 to 60 years of age.

There are several reasons why the respondents stayed at the hotel. Most of them were travelling for relaxation $(30.6 \%)$, while a number of others were for business purposes $(18.1 \%)$. A total of 31 respondents were travelling for educational purposes such as attending a conference or meeting, etc $(11.7 \%)$. The remaining balance of $18.1 \%$ were staying in a hotel for other purposes such as visiting friends or relatives, culture, fun, and sport.

\section{Preliminary analyses}

Table 1 Reliability Test

\begin{tabular}{lll}
\hline Dimension/Variable & No. of items & Cronbach's Alpha $(\mathrm{n}=265)$ \\
\hline Green Image & 9 & .963 \\
\hline Attributes & 6 & .946 \\
\hline Holistic & 3 & .926 \\
\hline Customer Satisfaction & 14 & .978 \\
\hline Cognitive & 7 & .965 \\
\hline Affective & 7 & .959 \\
\hline Customer Loyalty & 8 & .965 \\
\hline Attitudinal & 5 & .965 \\
\hline Behavioral & 3 & .916 \\
\hline
\end{tabular}

To verify the reliability of the instrument for the variables green image, customer satisfaction and customer loyalty, instrument reliability analysis was conducted. Based on Table 1, the three variables showed values of Cronbach's Alpha as above 0.90 . Sekaran and Bougie (2010) and Zainudin (2015) stated that values of Cronbach's Alpha that is more than 0.6 is acceptable for further investigation. This means all the variables involved have good value of reliability coefficient and are acceptable for further analysis.

Table 2 Normality Test

\begin{tabular}{llllllll}
\hline & Min & Max & Mean & Skewness & \multicolumn{2}{c}{ Kurtosis } \\
\hline & Statistic & Statistic & Statistic & Statistic & Std. Error & Statistic & Std. Error \\
\hline Green Image & 1.44 & 10.00 & 6.7466 & -.418 & .150 & .130 & .298 \\
\hline
\end{tabular}




\begin{tabular}{llllllll}
\hline $\begin{array}{l}\text { Customer } \\
\text { Satisfaction }\end{array}$ & 1.43 & 10.00 & 6.9725 & -.345 & .150 & -.233 & .298 \\
\hline $\begin{array}{l}\text { Customer } \\
\text { Loyalty }\end{array}$ & 1.00 & 10.00 & 6.7883 & -.385 & .150 & .141 & .298 \\
\hline
\end{tabular}

Normality tests were conducted to determine whether the data was normally distributed or not. This procedure is a basic requirement for conducting inferential statistical analysis. From Table 2, the result of the skewness and kurtosis tests conducted shows that the value of skewness is -.418 and kurtosis is .130 for the variable of green image, the skewness and the kurtosis for the customer

\section{Level of Green Image}

Table 3 shows the mean value of green image in Malaysian non-green hotels. The values shown is from the perception of a customer towards the green image applied or used in the hotel they stayed at. The mean values for all items of green image is 6 satisfaction variable is -.345 and -.233 respectively, and the value of skewness is -.385 and the kurtosis value is .141 for the customer loyalty variable. This results of the normality tests show that all the variables are normally distributed. According to Zainudin (2015), the data is normally distributed if the skewness and kurtosis value is 1.0 or lower.

and above. Since this study used a 10-point scale, the results reveal that all the items in this study were at a good level (6 and above) when the mean value is between 5.51 to 7.75 (Rist and Allen, 2011).

Table 3 Level of Green Image

\begin{tabular}{llllll}
\hline & $\mathrm{N}$ & Minimum & Maximum & Mean & Std.Deviation \\
\hline Physical facilities & 265 & 1 & 10 & 6.69 & 1.947 \\
\hline Interior design & 265 & 1 & 10 & 6.68 & 1.964 \\
\hline The quality of the products provided & 265 & 1 & 10 & 6.53 & 1.981 \\
& & & & & \\
\hline Staff performance & 265 & 1 & 10 & 6.76 & 1.917 \\
\hline Hotel's atmosphere & 265 & 1 & 10 & 6.65 & 2.010 \\
\hline Reputation & 265 & 1 & 10 & 6.89 & 1.842 \\
\hline External appearance & 265 & 1 & 10 & 6.75 & 1.969 \\
\hline Layout & 265 & 1 & 10 & 6.99 & 2.015 \\
\hline
\end{tabular}




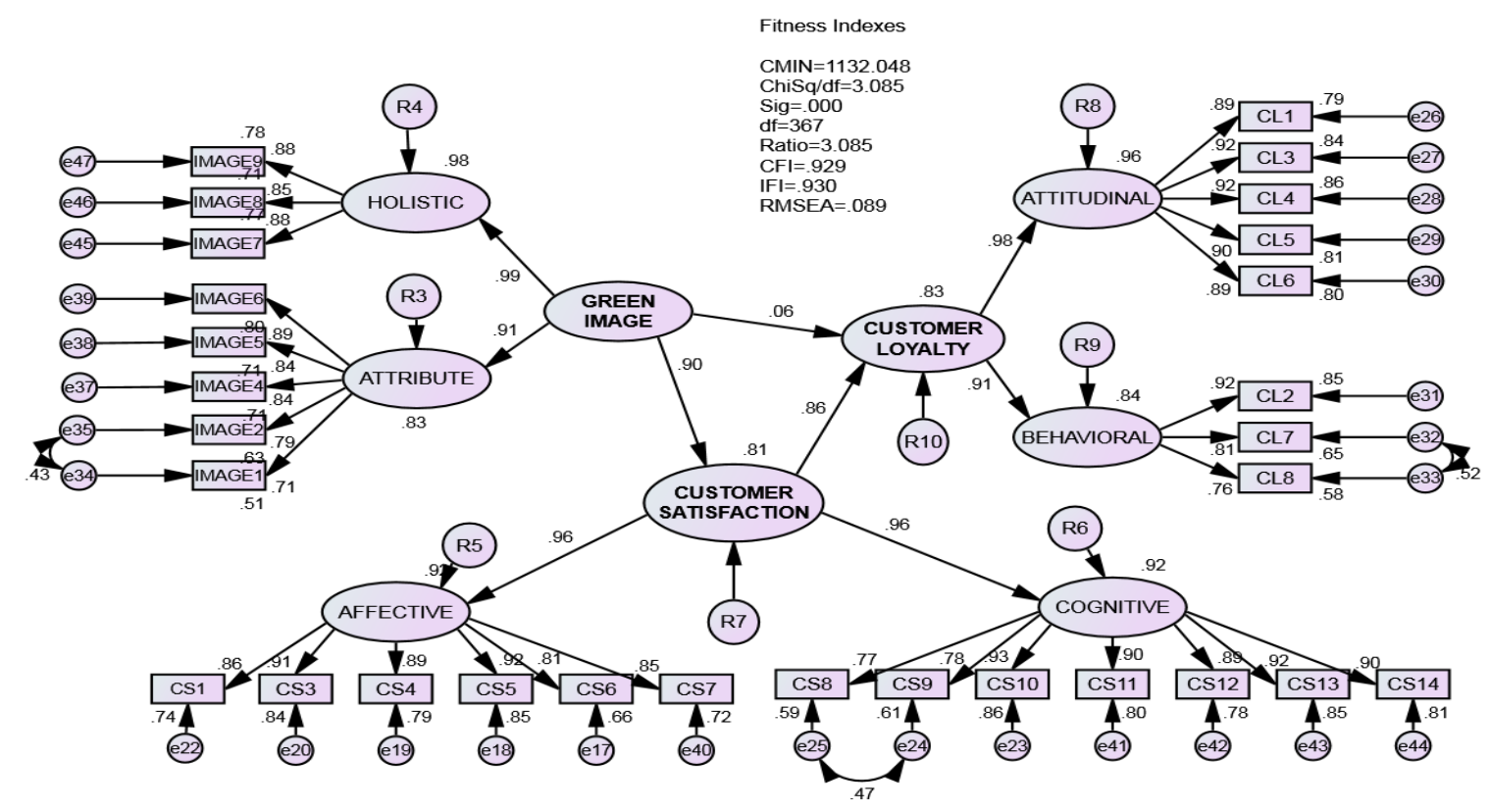

Figure 1 Structural Model of the Relationship between Green Image, Customer Satisfaction and Customer Loyalty

In Figure 1 the value of $\mathrm{R}^{2}$ for the whole model is 0.86. As a conclusion, the model is good since it could capture $86 \%$ of the estimate on endogenous construct by including certain exogenous constructs in the model. At the same time, most of the fitness indexes are good since the value achieved the requirement level and the factor loading for all items are good (above the required 0.6). This model indicates that $86 \%$ of the Customer Loyalty could be estimated by using two exogenous constructs in the model namely Green Image and Customer Satisfaction, while $81 \%$ of the Customer Satisfaction could be measured by using Green Image.

Table 4 The Path Regression Coefficient

\begin{tabular}{|c|c|c|c|c|c|c|c|}
\hline & & & Estimate & S.E. & C.R. & P-Value & Result \\
\hline $\begin{array}{l}\text { Customer } \\
\text { Loyalty }\end{array}$ & $<---$ & Green Image & 2.573 & .175 & 14.696 & .000 & Significant \\
\hline
\end{tabular}

Table 5 The Path Regression Coefficient and its Significance

\begin{tabular}{|c|c|c|c|c|c|c|c|}
\hline & & & Estimate & S.E. & C.R. & P-Value & Result \\
\hline $\begin{array}{l}\text { Customer } \\
\text { Satisfaction }\end{array}$ & $<---$ & Green Image & 1.186 & .083 & 14.367 & .000 & Significant \\
\hline $\begin{array}{l}\text { Customer } \\
\text { Loyalty }\end{array}$ & $<---$ & Green Image & 0.173 & .328 & 0.527 & .598 & Not significant \\
\hline $\begin{array}{l}\text { Customer } \\
\text { Loyalty }\end{array}$ & $<---$ & $\begin{array}{l}\text { Customer } \\
\text { Satisfaction }\end{array}$ & 2.026 & .274 & 7.401 & .000 & Significant \\
\hline
\end{tabular}

Table 5 and Table 6 show the significant values of the relationship between each variable in the model. Based on Table 5, the relationship between green image and customer loyalty is significant. However, when customer satisfaction is entered into the model, the significant value of the relationship 
changed. According to Table 6, there is a significant relationship between green image and customer satisfaction, and between customer satisfaction and customer loyalty. Meanwhile, the relationship between green image and customer loyalty is not significant.
From these results, it shows that customer satisfaction is a mediator in the relationship between green image and customer loyalty. Nevertheless, the effect of the relationship is still yet unknown. Thus, it is important to calculate the effect of the relationship using the standardized estimate.

Table 6 The standardized regression weights and its significance for each path

\begin{tabular}{llllll}
\hline \multirow{2}{*}{ Construct } & Path & Construct & $\begin{array}{c}\text { Standardized } \\
\text { Estimate }\end{array}$ & P-Value & Result \\
\hline Customer Satisfaction & $<---$ & Green Image & 0.902 & .000 & Significant \\
\hline Customer Loyalty & $<---$ & Green Image & 0.056 & .598 & Not Significant \\
\hline Customer Loyalty & $<---$ & Customer Satisfaction & 0.859 & .000 & Significant \\
\hline
\end{tabular}

According to Table 6, after calculating the effect of the indirect relationship, ie. between green image to customer satisfaction, and between customer satisfaction to customer loyalty, the result shows that the effect of the indirect relationship (0.775) is greater than the effect of the relationship between green image and customer loyalty (0.56). Since the indirect effect is larger than the direct effect, this

\section{The Effect Size in a Mediation Model}

The effect size is the amount of variance explained in the mediation model contributed by every single path (Zainudin, 2015). There are two steps that can be found in the model as follows:

$\mathrm{R}^{2}$ measures the effect size of an individual path in the model (3paths)

1) $R^{2} \mathrm{XM}$ represents squared partial correlation between Green Image and Customer Satisfaction (0.81)

2) $R^{2} X Y$ denotes squared partial correlation between Green Image and Customer Loyalty (0.69)

3) $R^{2}$ MY.X represents squared partial correlation between Customer Satisfaction and Customer Loyalty

4) when the influence of Green Image is removed from the model $(0.83-0.69=0.14)$

$\mathrm{R}^{2}{ }_{\text {MY } . \mathrm{X}}=0.83-0.69=0.14$

Since the effect size is 0.14 , thus the conclusion from this measure is that the effect size of Customer Satisfaction on Customer Loyalty is a medium range because according to Cohen (1988), the effect size of mediator when the range of $R^{2}$ is means mediation occurs in the relationship and both of the indirect paths (GI to CS and CS to CL) are

significant. The type of mediation here is Complete Mediation since the Direct Effect is not significant after the mediator enters the model.

between 0.13 to 0.26 . is categorized in medium range.

$\mathrm{R}^{2}$ measures the size of the mediated effect of a mediator in the model

The formula is $=\mathrm{R}^{2} \mathrm{MY}-\left(\mathrm{R}^{2} \mathrm{XMY}-\mathrm{R}^{2} \mathrm{XY}\right)$, where:

- $\quad \mathrm{R}^{2} \mathrm{XY}$ is the $\mathrm{R} 2$ for the model containing Green Image and Customer Loyalty only

- $\mathrm{R}_{\mathrm{MY}}^{2}$ is the $\mathrm{R} 2$ for the model containing Customer Satisfaction and Customer Loyalty only

- $\mathrm{R}^{2} \mathrm{XMY}$ is the $\mathrm{R} 2$ for the model containing Green Image, Customer Satisfaction and Customer Loyalty

$$
0.86-(0.83-0.69)=0.72
$$

Thus, based on Cohen (1988), the mediated effect size of the Customer Satisfaction (mediator) in the relationship between Green Image and Customer Loyalty is large (above 0.26). 


\section{CONCLUSION}

Since the awareness towards the environment increases globally, the managers of the non-green hotels should improve the image of their hotel to the conducive environment and did not impact negatively on the environment in accordance with the requirements of conscious customers. Besides that, it will bring higher satisfaction and loyalty among customers. The results indicate that customer satisfaction is a mediator in the

\section{REFERENCE}

Abdul Samad, M.H., Abdul Rahman, A.M and Ibrahim, F., 2008, Green Performance Ratings for Malaysian Buildings With Particular Reference to Hotels. International Conference on Environment Research and Technology (1CERT 08), 28-30 May 2008, Parkroyal Hotel, Penang.

Akbar, M. M. and Parvez, N., 2009, Impact Of Service Quality, Trust, And Customer Satisfaction On Customers Loyalty. ABAC Journal, 29(Mohamad., 1), 24-38

Al-Rousan, M.R. and Badaruddin 2010, Customer loyalty and the impacts of service quality: The case of five star hotels in Jordan International. Journal of Human and Social Sciences, 5(13), 886-892.

Alexander, S., 2002, Green hotels: Opportunities and resources for success (Portland: Zero Waste Alliance)

Allen, D.R. and Wilburn, M., 2002, Linking customer and employee satisfaction to the bottom line (Milwaukee: ASQ Quality Press)

Asean, 2013, ASEAN Tourism Standards. Date of access: 13/2/2014. http://www.aseantourism. travel/media/files/20130111081324_asean_tourism_s tandards_book.pdf

Bell, C., 2008, 100\% PURE New Zealand: Branding for back-packers. Journal of Vacation Marketing, 14(4), 345-355.

Burns, A. C., and Ronald F. Bush, R.F., 2014, Marketing research (7th ed.) (New Hersey: Pearson)

Cardozo, R.N., 1965, An experimental study of customer effort, expectation and satisfaction. Journal of Marketing Research, 2, 244-249.

Caruana, A., Money, A. H. and Berthon, P.R., 2000, Service quality and satisfaction-the moderating role of value. European Journal of Marketing, 3(11/12), 1338-1352.

CENTRAL INTELLIGENCE AGENCY (CIA), 2015). The World Factbook- Environmental- Current issues, retrieved 24 August 2015, from relationship between green image and customer loyalty and the effect size of customer satisfaction is large. This means that customer satisfaction is an important thing to consider since having customers who are satisfied with the facilities and the environment provided by the hotel will increase their loyalty to the hotel and also increase their patronage.

https://www.cia.gov/library/publications/the-world factbook/fields/2032.html

Coelho, P.S., and Esteves, S. P., 2007, The choice between a five-point and a ten-point scale in the framework of customer satisfaction measurement. International Journal of Market Research, 49(3), 313339.

Cohen, J., 1988, Statistical power analysis for the behavioral sciences (2nd ed.) (Hillsdale, NJ: Lawrence Earlbaum Associates)

Cohen, S. A., Prayag, G. and Moital, M., 2014, Consumer behavior in tourism: Concepts, influences and opportunities. Current Issues in Tourism, 17(10), 872-909

Dominici, G. and Guzzo, R., 2010, Customer satisfaction in the hotel industry: A case study from Sicily. International Journal of Marketing Studies, 2(2), 3-12.

Echtner, C.M., and Ritchie, B.J.R., 1991, The meaning and measurement of destination image. The Journal of Tourism Studies, 2(2), 2-12.

ECONOMIC PLANNING UNIT, 2015, Eleventh Malaysia Plan 2016-2020. Date of access: 16/9/2015. http://rmk11.epu.gov.my/book/eng/Elevent-MalaysiaPlan/index.html

GHA, 2013, What are green hotels? Date of Access: $15 / 12 / 2013$.

http://www.greenhotels.com/whatare.htm

Han, H., Hsu, L.J. and Lee, J.S., 2009, Empirical investigation of the roles of attitudes toward green behaviors, overall image, gender, and age in hotel customers' eco-friendly decision-making process. International Journal of Hospitality Management, 28, 519-528.

Han, H., Hsu, L.J. and Sheu, C., 2010, Application of the Theory of Planned Behavior to green hotel choice: Testing the effect of environmental friendly activities. Tourism Management, 31, 325-334 
Hartmann, P. and Ibanez, V.A., 2006, Green value added. Marketing Intelligence and Planning, 24(7), 673-680.

Heisterkamp, M., 2009, Guests expect more from green programs. Hotel \& motel management: Green. Date of access: 15/12/2013. http://www.hotelmanagement.net/heisterkamp

Hill, N., Roche, G and Allen, R., 2007, Customer satisfaction: The customer experience through the customer's eyes (London: Cogen Publishing)

JamaL, A. and Naser, K., 2002, Customer satisfaction and retail banking: an assessment of some of the key antecedents of customer satisfaction in retail banking. The International Journal of Bank Marketing, 20(4), 146-60.

Jeong, E. and Jang, S., 2010, Effects of restaurant green practices: Which practices are important and effective? Caesars Hospitality Research Summit. Paper 13.

Kandampully, J., and Suhartanto, D., 2000, Customer loyalty in the hotel industry: The role of customer satisfaction and image. International Journal of Contemporary Hospitality Management, 12(6), 346351.

Kandampully, J., and Suhartanto, D., 2003, The Role of Customer Satisfaction and Image in Gaining Customer Loyalty in the Hotel Industry. Journal of Hospitality \& Leisure Marketing, 10(1/2), 3-26.

Kang, K.H., Stein, L. Heo, C.Y. and Lee, S., 2012, Consumers' willingness to pay for green initiatives of the hotel industry. International Journal of Hospitality Management, 31, 564-572.

Kasim, A., 2004, Socio-environmentally responsible hotel business: Do tourists to Penang Island, Malaysia care? Journal of Hospitality \& Leisure Marketing, 11(4), 5-28.

Khan, S., 2013, Determinants of Customer Retention in Hotel Industry, Journal Of Applied Economics And Business, 1(3), 42-64

Kotler, P. and Armstrong, G., 1996, Principles of marketing (7th Ed.) (New Jersey: Prentice Hall PTR)

Kotler, P., and Gertner, D., 2002, Country as brand, product, and beyond: A place marketing and brand management perspective. Journal of Brand Management, 9(4-5), 249-261.

Krejcie, R. V., and Morgan, D. W., 1970, Determining sample size for research activities. Educational and Psychological Measurement, 30, 607-610.

Lee, J. S., Hsu, J. L., Han, H. and Kim, Y., 2010, Understanding how consumers view green hotels: how a hotel's green image can influence behavioural intentions, Journal of Sustainable Tourism, 18(7), 901-914.
Lee, J.L., James, J.D. and KIM, Y. K., 2014, A reconceptualization of brand image. International Journal of Business Administration, 5(4), 1-11.

Lita, R.P., Surya, S., Ma'ruf, M. and Syahrul, L., 2014, Green attitude and behavior of local tourists towards hotels and restaurants in West Sumatra, Indonesia, Procedia Environmetal Scences, 20, 261270 .

Maghzi, A., Abbaspour, B., Eskandarian, M. and Abdul Hamid, A. B., 2011, Brand trust in hotel industry: Influence of service quality and customer satisfaction. International Proceedings of Economics Development \& Research, 24, 4

Nor Azila, M. N. and Kumar, D., 2014, ECO friendly 'activities' VS ECO friendly 'attitude': Travelers intention to choose green hotels in Malaysia. World Applied Sciences Journal, 30(4), 506-513

Nurul Syaqirah, Z. and Putra Faizurrahman, Z., 2014, Managing customer retention of hotel industry in Malaysia. Procedia-Social and Behavioral Sciences, 130, 379-389.

Oliver, R. L.,1999, Whence Consumer Loyalty? Journal of Marketing, 63, 33-44.

Rist, S and Allen, D., 2011, Tales from the Field: Evaluating a University Residential Living- Learning Community. Date of Access: 31/3/2016. http://www.performancexpress.org/2011/07/talesfrom-the-field-evaluating-a-university-residentialliving-learning-community/

Sekaran, U. and Bougie, R., 2010, Research methods for business: A skill building approach. (West Sussex: John Wiley \& Sons Ltd)

Siti Nabiha, A.K.,. George, R.A, Abdul Wahid, N, Amran, A., Abustan, I and Mahadi, R., 2011, A Field Survey of Environmental Initiatives at Selected Resorts in Malaysia, World Applied Sciences (12) (Special Issue of Tourism \& Hospitality), 56-63

Siti Nabiha, A.K., and Nor Hasliza M.S., 2015, Tourism planning and stakeholders' engagement: the case of Penang Island. Problems and Perspectives in Management, 13(2), 269-276

Skogland, I. and Siguaw, J.A., 2004, Are you satisfied customer loyal? Cornell Hotel and Restaurant Administration Quarterly, 45(3), 221-234.

Smith, E.,E. and Perks, S., 2010, A perceptual study of the impact of green practice implementation on the business functions, Southern African Business Review, 14 (3), 1-29

UNITED NATION WORLD TOURISM ORGANIZATION (UNWTO), 2014), Tourism highlights: 2014 edition (World Tourism Organization, Madrid)

Walker, D.H.T., 1994, An Investigation into Factors that Determine Building Construction time 
Performance. Unpublished PhD. Thesis, Royal Melbourne Institute of Technology, Melbourne, Australia.

Wiele, T. V., Boselie P. and Hesselink, M., 2002, Empirical evidence for the relationship between customer satisfaction and business performance. Managing Service Quality, 12(3), 184 -193

Wittink, D.R. and Bayer, L.R., 1994, The Measurement Imperative: Empirical results on the number of scale points give managers a reliable gauge for assessing customer satisfaction. Marketing Research, 6 (4), 14-22.
Wolff, C., 2008, Second Nature. Lodging Hospitality, 64(2), 24-26

Zainudin, A., 2015, SEM made simple (Bangi: MPWS Rich Publication)

Zam, Z. M., Tengku, R. T. A., Azni, S.S. and Mai, F.M.B.M., 2014, Intention to visit green hotel in Malaysia: The impact of personal traits and marketing strategy, International Journal of Business and Social Science, 5(7), 167-173. 